\title{
In vitro rumen fermentation of diets with different types of condensed tannins derived from sainfoin (Onobrychis viciifolia Scop.) pellets and hazelnut (Corylus avellana L.) pericarps
}

Article

Accepted Version

Niderkorn, V., Barbier, E., Macheboeuf, D., Torrent, A., Mueller-Harvey, I. and Hoste, H. (2020) In vitro rumen fermentation of diets with different types of condensed tannins derived from sainfoin (Onobrychis viciifolia Scop.) pellets and hazelnut (Corylus avellana L.) pericarps. Animal Feed Science and Technology, 259. 114357. ISSN 0377-8401 doi:

https://doi.org/10.1016/j.anifeedsci.2019.114357 Available at https://centaur.reading.ac.uk/87252/

It is advisable to refer to the publisher's version if you intend to cite from the work. See Guidance on citing.

To link to this article DOI: http://dx.doi.org/10.1016/j.anifeedsci.2019.114357

Publisher: Elsevier

All outputs in CentAUR are protected by Intellectual Property Rights law, including copyright law. Copyright and IPR is retained by the creators or other copyright holders. Terms and conditions for use of this material are defined in 
the End User Agreement.

www.reading.ac.uk/centaur

\section{CentAUR}

Central Archive at the University of Reading

Reading's research outputs online 
2 In vitro rumen fermentation of diets with different types of condensed tannins derived from

6 V. Niderkorn*1 ${ }^{1}$, E. Barbier ${ }^{2}$, D. Macheboeuf ${ }^{1}$, A. Torrent ${ }^{1}$, I. Mueller-Harvey $^{3}$, H. Hoste ${ }^{4}$

$8{ }^{1}$ Université Clermont Auvergne, INRA, VetAgro Sup, UMR Herbivores, F-63122 Saint-Genès

9 Champanelle, France

${ }^{2}$ MG2MIX, Zone d'activité de la Basse Haye, Châteaubourg F-35220, France

${ }^{3}$ School of Agriculture, Policy and Development, University of Reading, P.O. Box 236, Reading

${ }^{4}$ Université de Toulouse, ENVT, 23 Chemin des Capelles, Toulouse F-31076, France

* Corresponding author. Tel.: +33 473624069

E-mail address: vincent.niderkorn@inra.fr 
Abstract

Information is lacking on the specific biological activity of feeds containing different types of condensed tannin (CT) on rumen fermentation characteristics. The aim of this study was to evaluate the in vitro rumen fermentation parameters of diets including sainfoin (Onobrychis viciifolia Scop.) pellets (PS) and/or hazelnut (Corylus avellana L.) pericarps (HP) using a batch culture system for $24 \mathrm{~h}$. The treatments were a basal diet consisting of (dry matter (DM) basis) $800 \mathrm{~g} / \mathrm{kg}$ hay from permanent grassland and $200 \mathrm{~g} / \mathrm{kg}$ concentrate mix (control), the basal diet $+30.4 \%$ PS, the basal diet $+8.2 \%$ freeze-dried HP, and the basal diet $+15.2 \%$ PS + 4.1\% HP. The diets were adjusted to be isotannic ( $20 \mathrm{~g} / \mathrm{kg} \mathrm{DM}$, except for the control) and isoproteic $(132 \mathrm{~g} / \mathrm{kg} \mathrm{DM})$. Total gas and methane $\left(\mathrm{CH}_{4}\right)$ productions were measured after 3.5 $\mathrm{h}$ and $24 \mathrm{~h}$ of incubation in buffered rumen fluid from sheep. At the end of incubation, $\mathrm{pH}$, in vitro DM degradability (IVDMD) and the concentration of fermentation end-products in the medium were also measured. The CT structures in PS and HP, determined by the thiolysis method, were very different: PS had mostly prodelphinidins and HP mostly procyanidins. After $24 \mathrm{~h}$ of incubation, the total gas and $\mathrm{CH}_{4}$ productions and IVDMD were greater for the basal diet than for the $\mathrm{CT}$-containing diets $(P<0.001)$. The $\mathrm{CH}_{4}$ production increased significantly with the diet + HP in the presence of polyethylene glycol (PEG, $4000 \mathrm{Da}$ molecular weight), a CT-inactivating compound $(P<0.001)$, and tended to increase for the diet + PS $(P=0.062)$. The volatile fatty acid (VFA: acetate, propionate, butyrate, minor and isoVFA) net productions were similar among treatments except for valerate (the lowest for PScontaining diets, $P=0.003$ ), while the $\mathrm{NH}_{3}$ concentration was lower for the diet $+\mathrm{PS}$ (with a significant PEG effect) than for the diets including HP, and was highest for the basal diet. It was concluded that the inclusion of PS and HP in a basal diet for ruminants results in lower 
rumen fermentability and that their $\mathrm{CT}$ decreased $\mathrm{CH}_{4}$ production and protein degradability. The PS were more effective than HP for reducing rumen protein degradability with a potential increase of duodenal nitrogen $(\mathrm{N})$ flow.

Keywords: rumen fermentability, protein degradability, methane, tannin-containing feeds, prodelphinidins, procyanidins

\section{Abbreviations}

ADF, acid detergent fibre expressed inclusive of residual ash; aNDF, neutral detergent fibre assayed with a heat-stable amylase and expressed inclusive of residual ash; $\mathrm{CP}$, crude protein; CT, condensed tannins; $\mathrm{CH}_{4}$, methane; DM, dry matter; HP, hazelnut pericarps; IVDMD, in vitro $\mathrm{DM}$ degradability; $\mathrm{mDP}$, mean degree of polymerisation; $\mathrm{N}$, nitrogen; $\mathrm{NH}_{3}$, ammonia; OM, organic matter; PC, procyanidins; PD, prodelphinidins; PEG, polyethylene glycol 4000; PS, pellets of sainfoin; VFA, volatile fatty acids.

\section{Introduction}

The livestock sector plays an important role in climate change as it accounts for $14.5 \%$ of human-induced greenhouse gases emissions. Ruminant production contributes to about twothirds of the sector's emissions under the form of nitrous oxide $\left(\mathrm{N}_{2} \mathrm{O}\right)$, methane $\left(\mathrm{CH}_{4}\right)$ and carbon dioxide $\left(\mathrm{CO}_{2}\right)$, which are also losses of nitrogen $(\mathrm{N})$, energy and organic matter that undermine efficiency and productivity. Feed production and enteric fermentation from ruminants are the two main sources of emissions, representing 45 and $39 \%$ of sector emissions, respectively (Gerber et al., 2013).

Among the principles proposed for the design of sustainable ruminant production systems in the context of agroecology, practices are put forward that stimulate natural processes to 
close system loops, reduce inputs and pollution, and improve animal health, (Dumont et al., 2013). Improved feeding strategies offer a relevant level of action, especially when non-food resources such as forage species or by-products from the human food industry are used.

Some natural resources such as forage legumes or by-products from the agroindustry contain condensed tannins (CT; syn. proanthocyanidins) consisting in polymers of flavan-3-ol units which have the potential to reduce pollution by decreasing $\mathrm{CH}_{4}$ emissions and urinary $\mathrm{N}$ losses through their ability to bind proteins (Mueller-Harvey et al., 2019). In addition, CT can also help at controlling gastrointestinal nematodes, including small ruminant strains that are multi-resistant against synthetic anthelmintic drugs (Gaudin et al., 2016). However, considerable variability in the chemistry and the biological activity of CT has been observed among natural resources. Although it had been widely assumed that CT act from a dosedependent manner, there is some evidence that the characteristics of CT play also an important role on their activity in the rumen (Huyen et al., 2016a). Two structural features of CT appear to merit particular attention: the structural characteristics of flavanols and the size of polymers (Hatew et al., 2016). The structural differences consist in whether the flavonol is (epi)gallocatechin giving rise to prodelphinidin (PD) or (epi)catechin giving rise to procyanidin $(\mathrm{PC})$, and in the mean degree of polymerisation $(\mathrm{mDP})$. As the structural composition of CT is uncommonly determined, very little is known on which CT traits are best to decrease $\mathrm{CH}_{4}$ production and excessive protein degradation in the rumen with contradictory results in the literature (Hatew et al., 2015; Naumann et al., 2018). Moreover, to date, there is no information on how different CT traits could be potentially complementary when they are incubated together.

The aim of this study was to evaluate the effects on in vitro rumen fermentation parameters of including in a basal diet two resources contrasting by their CT characteristics, namely hazelnut pericarps (HP, Corylus avellana L.), which contain PC-type CT or pellets of sainfoin 
(PS, Onobrychis viciifolia Scop.), which contain PD-type CT. In addition, these two resources were tested when mixed in a same diet to detect possible associative effects between them.

\section{Materials and methods}

\subsection{Treatments and plant materials}

Four diets were tested: i) a control basal diet consisting of, on a dry matter (DM) basis, 800 $\mathrm{g} / \mathrm{kg}$ hay from permanent grassland (INRA Theix, $810 \mathrm{~m}$ above sea level, first cut, harvested on 5 June 2015) containing approximately $70 \%$ grasses (mainly Dactylis glomerata, Lolium perenne, Festuca), 25\% dicotyledonous species including 5\% Trifolium repens, and $200 \mathrm{~g} / \mathrm{kg}$ concentrate mix containing $320 \mathrm{~g} / \mathrm{kg}$ barley, $180 \mathrm{~g} / \mathrm{kg}$ rapeseed meal, $150 \mathrm{~g} / \mathrm{kg}$ wheat, $110 \mathrm{~g} / \mathrm{kg}$ beet pulp, $180 \mathrm{~g} / \mathrm{kg}$ other grains and $60 \mathrm{~g} / \mathrm{kg}$ molasses and minerals, ii) the basal diet + PS provided by the company MG2MIX (Châteaubourg, France, cv. Multifolia Perly, $3^{\text {rd }}$ cut from swards established around Viâpres-le-Petit, France, in 2015, high PD/PC ratio), iii) the basal diet + freeze-dried HP provided by the company Inovfruit (Mussidan, France, low PD/PC ratio), and iv) the basal diet + PS + HP. A treatment in which the basal diet was supplemented with both HP and PS was added to determine whether mixing these CT-containing resources could produce associative effects on rumen fermentation characteristics. For the basal diet, the characteristics of hay was: $\mathrm{DM}=950 \mathrm{~g} / \mathrm{kg}$ fresh weight, organic matter $(\mathrm{OM})=902 \mathrm{~g} / \mathrm{kg} \mathrm{DM}$, crude protein $(\mathrm{CP})=86 \mathrm{~g} / \mathrm{kg} \mathrm{DM}$, (neutral detergent fibre) aNDF $=528 \mathrm{~g} / \mathrm{kg} \mathrm{DM}$, acid detergent fibre $(\mathrm{ADF})=290 \mathrm{~g} / \mathrm{kg} \mathrm{DM}$, in vitro digestibility $=615 \mathrm{~g} / \mathrm{kg} \mathrm{DM}$. The chemical composition of concentrate mix was: $\mathrm{DM}=913 \mathrm{~g} / \mathrm{kg}$ fresh weight, $\mathrm{OM}=935 \mathrm{~g} / \mathrm{kg} \mathrm{DM}, \mathrm{CP}=170 \mathrm{~g} / \mathrm{kg} \mathrm{DM}$, cellulose $=87 \mathrm{~g} / \mathrm{kg} \mathrm{DM}$ and starch $=300 \mathrm{~g} / \mathrm{kg}$ DM. The characteristics of PS and HP are presented in Table 1. The treatments were prepared to be isotannic ( $20 \mathrm{~g} / \mathrm{kg}$ of CT, except for the basal diet) and isoproteic (132 g/kg, adjusted with casein, Sigma-Aldrich, Saint Louis, MO, 
USA). It represented 30.4\% PS in the diet + PS, 8.2\% HP in the diet + HP, and $15.2 \%$ PS + 4.1\% HP in the diet + PS + HP.

\subsection{In vitro rumen fermentation assay}

All experimental procedures were conducted in accordance with the European Union Directive 2010/63/EU, reviewed by the local ethics committee (C2E2A, “Comité d'Ethique pour l'Expérimentation Animale en Auvergne") and authorised by the French Ministry for Research (no. 7138-2016092709177605-V5).

Plant substrate $(600 \pm 0.5 \mathrm{mg}$ in total) was placed in $120 \mathrm{ml}$ serum bottles, pre-warmed at $39 \pm 0.5^{\circ} \mathrm{C}$ and flushed with $\mathrm{N}_{2}$ to eliminate the oxygen present inside. Rumen fluid was collected before morning feeding from three cannulated sheep ( $62 \pm 7 \mathrm{~kg}$ on average) fed daily $1200 \mathrm{~g}$ of a diet composed of, per $\mathrm{kg}$ (as fed), permanent grassland hay, first cut (800 g) and the same concentrate mix used for the basal diet (400 g). Withdrawing and handling of rumen fluid were as described previously (Macheboeuf et al., 2008). Forty ml of buffered rumen fluid (strained rumen fluid diluted 1:2 (v/v) in an anaerobic phosphate:carbonate buffer solution, initial $\mathrm{pH} 6.89 \pm 0.02$ ) was added in the serum bottle, which were subsequently sealed hermetically with butyl rubber stopper and aluminium crimp seals. The buffer solution was prepared as described by Goering and Van Soest (1970) and modified by Niderkorn et al. (2011). The effects of CT were assessed by testing the treatments with and without polyethylene glycol (PEG, 4000 Da molecular weight, $2.3 \mathrm{~g} / \mathrm{l}$ ) in the incubation medium, a compound that can bind and inactivate CT. Blanks without any plant substrate (only buffered rumen fluid) were incubated during the different runs. All bottles were incubated in a shaking water bath at $39^{\circ} \mathrm{C}$. Samples of buffered rumen fluid were also taken at time 0 to determine volatile fatty acids (VFA) and ammonia $\left(\mathrm{NH}_{3}\right)$ present in the inoculum. Each treatment was repeated three times over two weeks. 
After $3.5 \mathrm{~h}$ and $24 \mathrm{~h}$ of incubation, the gas production was recorded using the pressure transducer technique, as described by Theodorou et al. (1994) and gas samples were taken from the headspace of the serum bottles for determination of gas composition $\left(\mathrm{CH}_{4}, \mathrm{CO}_{2}\right)$.

After $24 \mathrm{~h}$, the fermentation was stopped, the entire content of each serum bottle was transferred into a pre-weighed Falcon tube, and tubes were centrifuged at 3,400 $\times g$ for 10 min at $4{ }^{\circ} \mathrm{C}$. After sampling the supernatant for $\mathrm{VFA}$ and $\mathrm{NH}_{3}-\mathrm{N}$ determination (for details, see Niderkorn et al. (2012), the serum bottle was washed twice with distilled water to recover all the nondegraded particles that were transferred into the Falcon tube. Tubes were again centrifuged at $3,400 \times g$ for $10 \mathrm{~min}$ at $4{ }^{\circ} \mathrm{C}$, the supernatant was removed, and the $\mathrm{DM}$ of the residue was determined to calculate in vitro DM degradability (IVDMD).

\subsection{Analytical methods}

Plant substrates and residues were analysed for DM by oven-drying at $103 \pm 0.5{ }^{\circ} \mathrm{C}$ for $48 \mathrm{~h}$, and $\mathrm{OM}$ by ashing at $550{ }^{\circ} \mathrm{C}$ for $6 \mathrm{~h}$ in a muffle furnace. The aNDF and ADF contents were determined according to the method described by Van Soest et al. (1991), using a Fibre Analyser (Ankom Technology Corporation, Fairport, NY, USA). The CP content was determined by the Dumas combustion method (AOAC, 1995) using a rapid N-cube protein/N apparatus (Elementar Americas Inc., Mt Laurel, NJ, USA). The in vitro digestibility of hay was evaluated according to the pepsin-cellulase method described by Aufrère and MichaletDoreau (1988). The gas composition $\left(\mathrm{CH}_{4}\right.$ and $\left.\mathrm{CO}_{2}\right)$ was determined by gas chromatography using a MicroGC 3000A (Agilent Technologies, France). The individual VFA (acetate, propionate, butyrate, valerate, caproate, isobutyrate, isovalerate) in the supernatant fraction was measured by gas chromatography and $\mathrm{NH}_{3}$ was measured by Berthelot reaction (Weatherburn, 1967). The IVDMD was determined by difference between DM of plant material before the fermentation and DM of residue after $24 \mathrm{~h}$ of fermentation. The CT were 
analysed by direct thiolysis of freeze-dried samples with benzyl mercaptan at $40{ }^{\circ} \mathrm{C}$ for $1 \mathrm{~h}$ to provide quantitative and qualitative information (Gea et al., 2011). In brief, the thiolysis reaction releases the terminal units as the catechin, epicatechin, gallocatechin, epigallocatechin and the extension units as their benzylmercaptan derivatives. Thiolysis provides quantitative data the content of extractable and unextractable CT ( $\mathrm{g} \mathrm{CT} / \mathrm{kg} \mathrm{DM}$ ), and information on CT structures in terms of PD/PC and cis/trans-flavan-3-ol ratios (mol \%) and mDP values.

\subsection{Statistical analysis}

Each vessel was considered as an experimental unit. All variables were analyzed using the PROCMIXED procedure by SAS (Mixed procedure, version 9.2; SAS Institute Inc., Cary, NC, USA). The type of diet, PEG and their interaction were used as fixed effects and incubation day as random factor using the following model:

$Y_{i j k}=\mu+D_{i}+P_{j}+(D \times P)_{i j}+e_{i j}$

where $Y_{i j k}$ is the dependent variable, $\mu$ the overall mean, $D_{i}$ the type of diet $(j=4), P_{j}$ the effect of PEG ( $\mathrm{j}=2$, without and without the presence of PEG), $(\mathrm{D} \times \mathrm{P})_{\mathrm{ij}}$ the interaction of type of diet and PEG effect, and $e_{i j}$ the residual error term. Significance was declared at $\mathrm{P}<0.05$.

\section{Results}

\subsection{CT characteristics of resources}

The two CT-containing resources differed in terms of CP (PS > HP) and CT (HP > PS) contents (Table 1), but the treatments have been adjusted to be isoproteic and isotannic. The CT structures also differed between PS and HP (Table 1): PS had mostly PD with a PD/PC ratio of 75:25 and $\mathrm{HP}$ had mostly $\mathrm{PC}$ with a $\mathrm{PD} / \mathrm{PC}$ ratio of 28:72. The mDP was 11.5 for PS and 13.3 for HP and the cis/trans-flavan-3-ol ratio was 85:15 for PS and 58:42 for HP. 


\subsection{In vitro gas production and composition}

197

198

In the early phase of the fermentation (until $3.5 \mathrm{~h}$ ), the total gas and $\mathrm{CH}_{4}$ productions per $\mathrm{g}$ of incubated DM were greater for the basal diet than for the diets including HP, themselves being greater than for the diet + PS ( $P=0.005$, data not shown). After $24 \mathrm{~h}$ of incubation, the total gas production per $\mathrm{g}$ of incubated DM was greater for the basal diet than for the diet $+\mathrm{HP}$ and the diet + PS, while the diet + HP + PS was intermediate $(P=0.002$, Figure $1 \mathrm{~A})$. For the diet $+\mathrm{HP}$, the presence of PEG significantly increased the gas production $(P=0.028)$. The $\mathrm{CH}_{4}$ production was higher for the basal diet than for the diet + HP + PS, itself being higher than for the two other treatments $(P<0.001$, Figure 1B). The presence of PEG significantly increased the $\mathrm{CH}_{4}$ production for the diet $+\mathrm{HP}(P=0.007)$ and tended to increase it for the diet $+\mathrm{PS}$ $(P=0.062)$.

\subsection{Other in vitro rumen fermentation characteristics}

The $\mathrm{pH}$ of the medium was lower for the basal diet than for the diet $+\mathrm{PS}(P=0.036$, Table 2). The IVDMD was greater for the basal diet than for the diet + HP and the diet + HP + PS, while the diet + PS had the lowest value $(P<0.001)$. The VFA net productions and profiles in the medium were similar among treatments except for valerate, which was higher for the basal diet than for the diet + PS and the diet + HP + PS $\left(P=0.003\right.$, Table 2). The $\mathrm{NH}_{3}$ concentration was lower for the diet + PS than for the diets including HP, and was the highest for the basal diet. Opposite PEG effects on $\mathrm{NH}_{3}$ concentration were also detected for the basal diet (incubation without PEG > with PEG, P=0.041) and the diet + PS (incubation without PEG < with PEG, $P=0.016$ ) (Figure 1C).

\section{Discussion}




\subsection{Fermentability of the diets including CT-containing resources}

In this study, the isotannic (except for the basal diet) and isoproteic substrates with different CT types in HP and PS allowed us to investigate the relationship between CT structure and their effects on rumen fermentation characteristics. Compared to the basal diet, the fermentability of the diets including PS and/or HP was negatively affected early in the incubation period as shown by the lower total gas productions after $3.5 \mathrm{~h}$ of incubation. After $24 \mathrm{~h}$ of incubation, the fermentability was still reduced as evidenced by the lower values observed on total gas production and IVDMD. These results can be explained by the substitution of a part of the basal diet by less fermentable resources, but likely through different mechanisms. In the case of the inclusion of PS, it could be due to a low fibre degradability rather than a negative CT effect as this lack of fibre degradability/digestibility has been shown in in vitro and in vivo studies (Niderkorn et al., 2011; Huyen et al., 2016b) and because no significant difference in this study was observed between the diet + PS incubated with and without PEG. On the contrary, the increased total gas production when the diet + HP was incubated with PEG (CT inactivated) compared to the incubation without PEG indicates that the CT in HP decreased fibre fermentability. Interestingly, the total gas production for diet + PS + HP was not different compared from the basal diet, although the IVDMD was lower. This may indicate that the negative effect of PS on the fermentability was partly removed by a dilution effect from HP.

\subsection{Methane reduction}

In the early and late phases of the fermentation, the $\mathrm{CH}_{4}$ production was consistently higher for the basal diet compared to the CT-diets. The loss of fermentability due to CT when PS or HP were included in the basal diet is certainly a part of the explanation. Besides, the PEG effect observed after $24 \mathrm{~h}$ of incubation indicates clearly that CT in PS and HP also had an anti-methanogenic effect. These results are in line with the conclusions of the meta- 
analysis carried out by Jayanegara et al. (2012) that demonstrated that $\mathrm{CH}_{4}$ reduction in the presence of CT is mainly associated with a reduced apparent digestion of OM, and especially fibre. However, these authors mentioned that $\mathrm{CH}_{4} /$ apparently digestible $\mathrm{OM}$ also declined. In our study, after $3.5 \mathrm{~h}$ and $24 \mathrm{~h}$ of incubation, the values for the $\mathrm{CO}_{2}: \mathrm{CH}_{4}$ ratio were consistently higher for the CT-containing diets than for the basal diet $(P<0.001$, data not shown). These results indicate that the presence of PS or HP modifies the rumen metabolism towards a lower proportion of $\mathrm{CH}_{4}$ in the fermentation gas. Two hypotheses based on the literature can be proposed: a direct effect of CT on the archaea-methanogen populations and their activity (Saminathan et al., 2016) or a decrease of substrate for the $\mathrm{CH}_{4}$ formation through a reduction of $\mathrm{H}_{2}$ availability (Tavendale et al., 2005). In our study, the results for VFA net productions and profiles showed only a significant difference between treatments for valerate and a trend for caproate. In particular, acetate and propionate productions were similar and no PEG effect was detected on VFA (data not shown), indicating that the main fermentation pathways were not strongly affected by the different CT from PS and HP. Some authors have suggested that an inhibition of $\mathrm{CH}_{4}$ production can enhance fermentation pathways that require a net incorporation of $\mathrm{H}_{2}$ into the VFA produced from glucose, leading notably to increased valerate and caproate productions (Guyader et al., 2017). In our study, we observed indeed a trend towards an increase of caproate concentration with the diet $+\mathrm{HP}$, but the diet + PS led to the lowest valerate concentration. These results suggest that $\mathrm{H}_{2}$ may have been redirected differently according to the type of CT-containing resource, possibly due to the different structure of $\mathrm{CT}$ which has been shown to affect in vitro rumen fermentation characteristics (Huyen et al., 2016a). It has to noted that mixing PS and HP led to $\mathrm{CH}_{4}$ production higher than for the CT-containing resources taken individually, likely due to the higher total gas production. 


\subsection{Protein degradability}

Regarding the fate of nitrogenous compounds, our results showed clearly that the inclusion of PS and HP in the diet decreased the $\mathrm{NH}_{3}$ concentration in the fermentation medium. As the diets were isoproteic, it indicates that HP and PS resulted in a lower protein degradation or in a greater incorporation of $\mathrm{N}$ in microbial biomass through microbial protein synthesis. As we found that IVDMD, which can be partly linked to the microbial biomass, was lower in the presence of $\mathrm{HP}$ and PS, it is more probable that less protein was degraded to $\mathrm{NH}_{3}$. The ability of $\mathrm{CT}$ to form complexes with protein leading to their protection from ruminal degradation has been recognised for a long time (Min et al., 2003). This role of CT was confirmed in our study at least for the diet + PS for which the presence of PEG increased the $\mathrm{NH}_{3}$ concentration. On the other hand, we found the lowest $\mathrm{NH}_{3}$ concentration for the diet + PS, suggesting that CT from PS were more active at reducing protein degradation than the CT from HP as both diets were isotannic. It was reported that the size of CT is the key parameter controlling protein binding activity as demonstrated using bovine serum albumin, for which the activity clearly increased when the mDP values increased from 3 to 8 (Ropiak et al., 2017). However, according to these authors there were only small differences in the efficacies of larger CTs with mDP $>9$ to aggregate the proteins. In our study, the mDP of CT of PS and HP were similar (11 vs 13.5), suggesting that the size of these CT was not the main driver for the activity differences. More importantly, the PD/PC ratio was the main difference and our results suggest that a high $\mathrm{PD} / \mathrm{PC}$ ratio as in PS gave rise to more active $\mathrm{CT}$ in terms of protein binding activity than a low $\mathrm{PD} / \mathrm{PC}$ ratio as in HP. This hypothesis is consistent with the findings from Huyen et al. (2016a) who showed in vitro using CT extracts from different plants that the proportion of PD in CT had the largest effect on rumen fermentation characteristics. These authors argued that PD have more hydroxyl groups than PC, and thus they are more able to bind fibre and protein, and impact on their degradability. 


\section{Conclusions}

297

298

Under in vitro conditions, the inclusion of PS and HP in a basal diet for ruminants led to lowered rumen fermentability and also decreased $\mathrm{CH}_{4}$ production and protein degradability due to $\mathrm{CT}$ : the PD-rich CT in PS were more effective than the PC-rich CT in HP with a possible increase of duodenal $\mathrm{N}$ flow. The real impact on ruminant performances, the reduction in $\mathrm{CH}_{4}$ emissions and $\mathrm{N}$ urinary losses, and a potential increase in $\mathrm{N}$ use efficiency have to be evaluated in vivo.

\section{Acknowledgements}

This work was funded by the INRA metaprogram GISA (project STReP). The authors thank the staff from the Herbipole experimental unit (INRA, Theix) for the care of animals, Christos Fryganas from University of Reading for the CT analysis, and the companies MG2MIX (Châteaubourg, France) and Inovfruit (Mussidan, France) which supplied PS and HP, respectively.

\section{References}

AOAC, 1995. Official Methods of Analysis of the Association of Official Analytical Chemists, 15th ed. Association of Official Analytical Chemists Inc., Arlington, Virginia, USA.

Aufrère, J., Michalet-Doreau, B., 1988. Comparison of methods for predicting digestibility of feeds. Anim. Feed Sci. Technol. 20, 203-218.

Dumont, B., Fortun-Lamothe, L., Jouven, M., Thomas, M., Tichit, M., 2013. Prospects from agroecology and industrial ecology for animal production in the 21 st century. Animal 7, 10281043. 
Gaudin, E., Simon, M., Quijada, J., Schelcher, F., Sutra, J. F., Lespine, A., Hoste, H., 2016. Efficacy of sainfoin (Onobrychis viciifolia) pellets against multi resistant Haemonchus contortus and interaction with oral ivermectin: Implications for on-farm control. Vet. Parasitol. 227, 122-129.

Gea, A., Stringano, E., Brown, R.H., Mueller-Harvey I., 2011. In situ analysis and structural elucidation of sainfoin (Onobrychis viciifolia) tannins for high throughput germplasm screening. J. Agric. Food Chem. 59, 495-503.

Gerber, P.J., Steinfeld, H., Henderson, B., Mottet, A., Opio, C., Dijkman, J., Falcucci, A., Tempio, G., 2013. Tackling climate change through livestock - A global assessment of emissions and mitigation opportunities. Food and Agriculture Organization of the United Nations (FAO), Rome.

Goering, H.K., Van Soest, P.J., 1970. Forage fibre analyses (apparatus, reagents, procedures, and some applications). In: Agriculture Handbook No. 379. ARS-USDA, Washington, DC. Guyader, J., Ungerfeld, E.M., Beauchemin, K.A., 2017. Redirection of metabolic hydrogen by inhibiting methanogenesis in the rumen simulation technique (RUSITEC). Front.

Microbiol., 8, 393, 1-16.

Hatew, B., Hayot Carbonero, C., Stringano, E., Sales, L.F., Smith, L. M.J., Mueller-Harvey, I., Hendriks, W.H., Pellikaan, W.F., 2015. Diversity of condensed tannin structures affects rumen in vitro methane production in sainfoin (Onobrychis viciifolia) accessions. Grass forage sci., 70, 474-490.

Hatew, B., Stringano, E., Mueller-Harvey, I., Hendriks, W.H., Carbonero, C.H., Smith, L.M. J., Pellikaan, W.F., 2016. Impact of variation in structure of condensed tannins from sainfoin (Onobrychis viciifolia) on in vitro ruminal methane production and fermentation characteristics. J. Anim. Physiol. Anim. Nutr., 100, 348-360. 
Huyen, N.T., Fryganas, C., Uittenbogaard, G., Mueller-Harvey, I., Verstegen, M.W.A., Hendriks, W.H., Pellikaan, W.F. 2016a. Structural features of condensed tannins affect in vitro ruminal methane production and fermentation characteristics. J. Agric. Sci. 154, 14741487.

Huyen, N.T., Desrues, O., Alferink, S.J. J., Zandstra, T., Verstegen, M.W.A., Hendriks, W.H., Pellikaan, W.F., 2016b. Inclusion of sainfoin (Onobrychis viciifolia) silage in dairy cow rations affects nutrient digestibility, nitrogen utilization, energy balance, and methane emissions. J. Dairy Sci. 99, 3566-3577.

Jayanegara, A., Leiber, F., Kreuzer, M., 2012. Meta-analysis of the relationship between dietary tannin level and methane formation in ruminants from in vivo and in vitro experiments. J. Anim. Physiol. Anim. Nutr. 96, 365-375.

Macheboeuf, D., Morgavi, D. P., Papon, Y., Mousset, J. L., Arturo-Schaan, M., 2008. Doseresponse effects of essential oils on in vitro fermentation activity of the rumen microbial population. Anim. Feed Sci. Technol. 145, 335-350.

Min, B.R., Barry, T.N., Attwood, G.T., McNabb, W.C., 2003. The effect of condensed tannins on the nutrition and health of ruminants fed fresh temperate forages: a review. Anim. Feed Sci. Technol. 106, 3-19.

Mueller-Harvey, I., Bee, G., Dohme-Meier, F., Hoste, H., Karonen, M., Kolliker, R., Lüscher, A., Niderkorn, V., Pellikaan, W.F., Salminen, J.P., Skot, L., Smith, L.M.J., Thamsborg, S.M., Totterdell, P., Wilkinson, I., Williams, A.R., Azuhnwi, B.N., Baert, N., Grosse Brinkhaus A., Copani, G., Desrues, O., Drake, C., Engstrom, M., Fryganas, C., Girard, M., Huyen, N.T., Kempf, K., Malisch, C., Mora-Ortiz, M., Quijada, J., Ramsay, A., Ropiak, H.M., Waghorn, G.C., 2019. Benefits of condensed tannins in forage legumes fed to ruminants: importance of structure, concentration and diet composition. Crop Sci. 59, 961-885. 
Naumann, H., Sepela, R., Rezaire, A., Masih, S., Zeller, W., Reinhardt, L., Robe, J.T., Sullivan, M.L., Hagerman, A., 2018. Relationships between structures of condensed tannins from Texas legumes and methane production during in vitro rumen digestion. Molecules, 23, $2123,1-16$

Niderkorn, V., Baumont, R., Le Morvan, A., Macheboeuf, D., 2011. Occurrence of associative effects between grasses and legumes in binary mixtures on in vitro rumen fermentation characteristics. J. Anim. Sci. 89, 1138-1145.

Niderkorn, V., Mueller-Harvey, I., Le Morvan, A., Aufrère, J., 2012. Synergistic effects of mixing cocksfoot and sainfoin on in vitro rumen fermentation. Role of condensed tannins. Anim. Feed Sci. Technol. 178, 48-56.

Ropiak, H.M., Lachmann, P., Ramsay, A., Green, R.J., Mueller-Harvey, I., 2017.

Identification of structural features of condensed tannins that affect protein aggregation. PloS one, 12 , e0170768.

Saminathan, M., Sieo, C.C., Gan, H.M., Abdullah, N., Wong, C.M.V.L., Ho, Y.W., 2016.

Effects of condensed tannin fractions of different molecular weights on population and diversity of bovine rumen methanogenic archaea in vitro, as determined by high-throughput sequencing. Anim. Feed Sci. Technol. 216, 146-160.

Tavendale, M.H., Meagher, L.P., Pacheco, D., Walker, N., Attwood, G.T., Sivakumaran, S., 2005. Methane production from in vitro rumen incubations with Lotus pedunculatus and Medicago sativa, and effects of extractable condensed tannin fractions on methanogenesis. Anim. Feed Sci. Technol. 123, 403-419.

Theodorou, M.K., Williams, B.A., Dhanoa, M.S., McAllan, A.B., France, J., 1994. A simple gas production method using a pressure transducer to determine the fermentation kinetics of ruminant feeds. Anim. Feed Sci. Technol. 48, 185-197. 
391 Van Soest, P.J., Robertson, J.B., Lewis, B.A., 1991. Methods for dietary fiber, neutral

392 detergent fiber, and nonstarch polysaccharides in relation to animal nutrition. J. Dairy Sci. 74, $393 \quad 3583-3597$.

394 Weatherburn, M., 1967. Urease-Berthelot colorimetric method for in vitro determination of 395 urea. Anal. Chem. 39, 971-974. 